Summer 2013

\title{
Constitutionalization of Nongovernmental Certification Programs
}

Jaye Ellis

McGill University, Faculty of Law, jaye.ellis@mcgill.ca

Follow this and additional works at: https://www.repository.law.indiana.edu/ijgls

Part of the Constitutional Law Commons, and the International Law Commons

\section{Recommended Citation}

Ellis, Jaye (2013) "Constitutionalization of Nongovernmental Certification Programs," Indiana Journal of Global Legal Studies: Vol. 20 : Iss. 2 , Article 16.

Available at: https://www.repository.law.indiana.edu/ijgls/vol20/iss2/16

This Symposium is brought to you for free and open access by the Law School Journals at Digital Repository @ Maurer Law. It has been accepted for inclusion in Indiana Journal of Global Legal Studies by an authorized editor of Digital Repository @ Maurer Law. For more information, please contact rvaughan@indiana.edu.

\section{$\Psi$}

JEROME HALL LAW LIBRARY

INDIANA UNIVERSITY

Maurer School of Law
Bloomington 


\title{
Constitutionalization of Nongovernmental Certification Programs
}

\author{
JAYE ELLIS ${ }^{*}$
}

\begin{abstract}
Certification programs created by nonstate actors such as the Forest Stewardship Council and Marine Stewardship Council are innovative and potentially highly effective governance initiatives. This article works from the premise that these Councils can be understood as political authorities promulgating law. These Councils, and other actors like them, are generally analyzed from the point of view of governance, which triggers questions about their effectiveness and legitimacy. The approach adopted here shifts the focus to questions of their authority and the validity of the rules, standards, and decision-making processes that they have put in place. The Councils have put in motion elaborate networks of actors, creating interactions among social systems and making possible translations from the medium of one system to another. In this manner, the resources of these social systems are made available to the Councils: truth (science), money (economics), power (politics), legality (law), and so forth. One of the challenges that the Councils now face is to pursue the constitutionalization of these networks in the interest of protecting the autonomy of the range of social systems implicated in them while, at the same time, ensuring that these systems' resources are available within the network. Particular attention will be devoted to the role of law within the networks constituted by the Councils. The role of law is currently difficult to discern; law tends to be closely bound up with science and politics. The concept of the societal constitution serves to draw attention to the threats to law's autonomy within these networks and sheds light on the particular, and unique, contributions that law could make.
\end{abstract}

* Associate Professor, Faculty of Law and School of Environment, McGill University.

Indiana Journal of Global Legal Studies Vol. 20, Issue 2 (2013)

(C) Indiana University Maurer School of Law 


\section{INTRODUCTION}

The year 2012 should have been a banner year for international environmental law and politics. June 2012 was the fortieth anniversary of the watershed United Nations Conference on the Human Environment held in Stockholm, Sweden in $1972 .{ }^{1}$ The occasion was marked by the Rio +20 Summit, which attracted disappointingly few heads of state and little media attention. ${ }^{2}$ The year 2012 was also the year in which parties to the Kyoto Protocol were supposed to have met their first set of greenhouse gas emissions reductions, and the Protocol was to have been supplemented by a new instrument establishing a further and more ambitious set of goals for a second commitment period..$^{3}$ These and other disappointments lead civil society actors to turn their attention to alternative approaches to environmental governance that do not depend on state-based political authority or the validity of state-based law, though they may still tap into these resources. A growing number of initiatives seek to create economic incentives for industrial actors to meet higher standards for environmental protection than states appear capable of providing through domestic or international law.

This paper will concentrate on two organizations, the Forest Stewardship Council (FSC) ${ }^{4}$ and the Marine Stewardship Council

1. Report of the United Nations Conference on the Human Environment, Stockholm, June 5-16, 1972 (A/CONF.48/14 and Corr.1).

2. Rio+20: Le Brésil gagnant, la planète perdante, LE MONDE (June 22, 2012), available at http://www.lemonde.fr/idees/article/2012/06/22/rio-20-le-bresil-gagnant-laplanete-perdante_1723211_3232.html; Jonathan Watts \& Adam Vaughan, Rio+20 Summit Talks turn into Rubber-Stamp Job, THE GUARDIAN (June 20, 2012), available at http://www.theguardian.com/environment/2012/jun/20/rio20-earth-summit-talks. But see Simon Romero \& John M. Broder, Progress on the Sidelines as Rio Conference Ends, N.Y. TIMES (June 23, 2012), available at http://www.nytimes.com/2012/06/24/world/americas/rio20-conference-ends-with-someprogress-on-the-sidelines.html?_r=0.

3. Conference of the Parties to the United Nations Framework Convention on Climate Change, Decision 1/CMP.1: Consideration of commitments for subsequent periods for Parties included in Annex I to the Convention under Article 3, paragraph 9, of the Kyoto Protocol (FCCC/KP/CMP/2005/8/Add.1).

4. The FSC was founded in 1992 by a group of industry and civil society actors in the wake of the failure of states participating in the Rio Conference on Environment and Development to conclude a convention on forestry. History, An Innovative Idea Takes Root, FSC, https://ic.fsc.org/our-history.17.htm (last visited Oct. 1, 2013). The FSC pursues environmental, economic, and social goals, as set out in its Mission Statement. Our Vision and Mission, FSC, https://ic.fsc.org/vision-mission.12.htm (last visited Oct. 1, 2013) ("The Forest Stewardship Council A.C. (FSC) shall promote environmentally appropriate, socially beneficial, and economically viable management of the world's forests."). 
(MSC), ${ }^{5}$ which have put in place programs for the certification of forestry and fisheries products, respectively. These certification programs are enforced through networks of scientists, governments, media, industry actors, and members of civil society by means of market-based incentives. The success of these certification programs depends on the capacity of the Councils to translate ethical-political convictions about environmental protection, sustainable development, and social justice (in the case of the FSC) into economic incentives for industry actors to improve their environmental and social performance. ${ }^{6}$ This process of translation depends on a sequence of translations among the media of truth (science), money (economics), power (politics), legality (law), good or right (ethics) and others.

I argue that the Councils can usefully and meaningfully be described as public international authorities wielding formal, though nonstate-based, authority through standards, principles, rules, and criteria that can be understood as formal law. ${ }^{7}$ Looking at the Councils and their certification programs in this manner helps us to see certain potential shortcomings and weaknesses that are otherwise difficult to identify or analyze, but which come to the fore when we begin to ask questions about the functioning of these certification programs as part of a legal system. As we will see, the respective roles of many of the social systems implicated in the Councils' networks-notably law, science, politics, and economics-are fairly easy to discern. However, the manner in which these systems are brought together raises some concerns for the autonomy of the respective systems and the possibility of colonization of the certification programs by the logic of one or another among them. ${ }^{8}$ The discussion here will focus on potential threats to the autonomy of law. The FSC and the MSC have clearly sought to make both their substantive and procedural rules closely

5. The MSC was founded by the World Wildlife Federation and Unilever in 1996; it became an independent entity in 1998. Its mission is narrower than that of the FSC, focusing on sustainable exploitation of fisheries resources. Vision and Mission, MARINE STEWARDSHIP COUNCIL, http://www.msc.org/about-us/vision-mission (last visited Oct. 1, 2013) ("Our mission is to use our ecolabel and fishery certification programme to contribute to the health of the world's oceans by recognising and rewarding sustainable fishing practices, influencing the choices people make when buying seafood, and working with our partners to transform the seafood market to a sustainable basis."). The FSC and MSC will be referred to collectively as the Councils. Reference will also be made more generally to certification programs or certification organizations.

6. Lars H. Gulbrandsen, The Emergence and Effectiveness of the Marine Stewardship Council, 33 MARINE POLICY 654, 655 (2009).

7. See Errol Meidinger, The Administrative Law of Global Public-Private Regulation: The Case of Forestry, 17 EUR. J. OF INT'L L. 47, 49, 61 ff. (2006).

8. Poul F. Kjaer, Embeddedness through Networks: A Critical Appraisal of the Network Concept in the Oeuvre of Karl-Heinz Ladeur, 10 GERMAN L.J. 483, 495 (2009). 
resemble law, and they have succeeded, at least in a superficial way. However, they are in the process of repeating many of the mistakes that have been made by states at the domestic and international level as they seek to bring law to bear on environmental degradation. On the other hand, certain aspects of the Councils' approach (notably, the manner in which different types of expertise interact within the regimes and the potential for dynamic development of the Councils' standards) are potentially very promising, given the conditions of complexity and uncertainty under which environmental decision-making must take place.

The objects of the societal constitution are the regimes that have emerged around the FSC and MSC. ${ }^{9}$ The concept of a constitution that is not state-based has begun to gain acceptance in the literature..$^{10}$ The contention that a constitution may not apply to a particular polity and derive its legitimacy from that polity remains deeply troubling to many commentators. ${ }^{11}$ The FSC and MSC present themselves as acting in the public interest, ${ }^{12}$ and not just in the name of their members. ${ }^{13}$ However, they remain private actors, which have bestowed authority upon themselves. The public in whose name they purport to act is not a body politic with reasonably stable boundaries; it is a dynamic group of

9. See GUNTHER TEUBNER, Verfassungsfragmente. Gesellschaftlicher Konstitutionalismus in der Globalisierung $97 \mathrm{ff}$. (Suhrkamp. 2012) for a discussion of the constitution of a nonstate regime.

10. Ulrich K. Preuss, Disconnecting Constitutions From Statehood: Is Global Constitutionalism a Viable Concept?, in The TwiLight of Constitutionalism? 23 (Petra Dobner \& Martin Loughlin eds., 2010); Neil Walker, Beyond the Holistic Constitution?, in The TWILIGHT OF CONSTITUTIONALISM? 291, supra; Martin Loughlin, What is Constitutionalism?, in THE TWILIGHT OF CONSTITUTIONALISM? 47, supra. But see Mattias Kumm, The Best of Times and the Worst of Times: Between Constitutional Triumphalism and Nostalgia, in THE TwILIGHT OF CONSTITUTIONALISM? 201, 204, 212, supra, for a discussion of literature skeptical of this position and for his own critique of constitutions beyond the state.

11. For a discussion of the difficulties posed by a constitution not established on close interaction between a pouvoir constituant and a pouvoir constitué, see TEUBNER, supra note 9 , at $100 \mathrm{ff}$. A number of authors committed to the concept of a constitution beyond the state nevertheless point to the need for some form of legitimation by a polity, see Walker, supra note 10, 206; Petra Dobner, More Law, Less Democracy? Democracy and Transnational Constitutionalism, in THE TWILIGHT OF ConstiTUTIONALISM? 141, supra note 10.

12. See the mission statement of the FSC, supra note 4, and the MSC's mission statement, supra note 5 .

13. This is particularly true of the MSC, which is not a membership organization. See Karsten Nowrot, Marine Stewardship Council, in HANDBOOK OF TRANSNATIONAL ECONOMIC GovernanCe RegIMES (Christian Tietje \& Alan Brouder eds., 2009). 
stakeholders. ${ }^{14}$ As Teubner argues, the constitution ought to be understood not as constituting a body politic, but rather communications. ${ }^{15}$ Among the most important communications circulating throughout the regime are those among the social systems brought together in networks by the Councils. These networks, and the communications which flow through them, are essential, as the resources that the Councils are able to tap into are not their own: they are placed at the disposal of the certification programs by the various social systems that interact within the networks. The societal constitution draws our attention to ways in which the rough equilibrium among social systems could be upset and the certification programs colonized by one or another of the systems. The most obvious danger to the integrity of the Councils' projects is their colonization by economics, given their heavy reliance on market mechanisms. ${ }^{16}$ But the dangers of corruption by science, politics, and law are equally present. Closely related to this second point, the societal constitution directs attention to the particular role that law could play within this network, but also to the difficulties that law presently encounters in asserting and protecting its autonomy.

There is a further issue that will require attention-namely, what an autonomous body of law, operating within the Councils' networks, could look like. The concept of the societal constitution does not shed much light on the structure and content of a legal system beyond drawing attention to the contingency of those questions. Law takes a certain form in a given society due to a range of historical, cultural, and

14. The governance structure and decision-making processes of the two Councils provide for extensive involvement of a range of civil society actors. One example of the MSC's attempts to ensure openness and representativeness is its Stakeholder Council. See Stakeholder Council Terms of Reference, MARINE STEWARDSHIP COUNCIL, http://www.msc.org/about-us/governance/structure/msc-stakeholder-council/stakeholder-

council-terms-of-

reference/?searchterm $=$ stakeholder\%20council\%20terms\%20of\%20reference (last visited Oct. 1, 2013). With respect to the FSC, a good example is the tripartite governance structure of its General Assembly, with three chambers representing economic, social, and environmental interests. See Membership Chambers, FSC, https://ic.fsc.org/membershipchambers.77.htm (last visited Oct. 1, 2013). For different analyses of the move from citizen to stakeholder see Moritz Renner, The Dialectics of Transnational Economic Constitutionalism, in Karl Polany, Globalisation and the Potential of LAW IN Transnational MarKets 422 (Christian Joerges \& Josef Falke eds., 2011); Regine Kreide, Re-embedding the Market through Law? The Ambivalence of Juridification in the International Context, in KARL POLANY: GLOBALISATION AND THE POTENTIAL OF LAW IN TRANSNATIONAL MARKETS 44 ff., supra.

15. TEUBNER, supra note 9, at 103.

16. James Lawson \& Benjamin Cashore, The Application of the Theory of Social Autopoiesis to the Problem of Non-State Sanctioned, Market-Driven (NSMD) Governance, Forest Policy Centre, Internal Working Paper Series No. 120, 12. 
other factors, but it could very well have developed differently. In order to describe what I see as being law's potential role, and to identify the many ways in which the Councils' constitutions fall short in this respect, I turn to two bodies of literature: work on the rule of law in the welfare state and research on environmental decision-making and post-normal science.

\section{Certification Programs as EnVIronmental Governance NETWORKS}

The Councils rely heavily on democratic principles because they do not possess formal political authority, and they clearly require access to a resource that can enable them to offer resistance to the force of economic logic. Their standards have a certain credibility because they are not the creatures of industry associations. ${ }^{17}$ Furthermore, they have the backing of various segments of society through representative governance structures and decision-making processes that are accessible to more punctual input from members of civil society. ${ }^{18}$ The authority of science also supports them, the effect of which is present in various places in governance and decision-making. The credibility from this authority and the legitimacy derived from close attention to and respect for democratic principles allow Councils to produce effective certification programs. ${ }^{19}$ But if they rely solely on politics to generate

17. The MSC was initially launched by Unilever and the World Wildlife Fund for Nature, but was later constituted as an independent organization. Concerns were expressed about the participation of Unilever, a major manufacturer of fish products. See, e.g., Douglas H. Constance \& Alessandro Bonnano, Regulating the Global Fisheries: The World Wildlife Fund, Unilever, and the Marine Stewardship Council, 17 AGRICULTURE \& HUMAN VALUES 125, 131 (2000). See also Gulbrandsen, supra note 6, at 655.

18. Benjamin Cashore notes the reliance of the Councils and similar organizations on “'external audiences,' who are encouraged to accept the NSMD [nonstate market-driven] governance system based on economic material benefits ..., moral suasion ..., or because it has become an accepted and understandable practice." Benjamin Cashore, Legitimacy and the Privatization of Environmental Governance: How Non-State Market-Driven (NSMD) Governance Systems Gain Rule-Making Authority, 15 GoverNANCE 503, 511 (2002).

19. See Nowrot, supra note 13, at 724 ff. (2009). Nowrot distinguishes between "input-oriented" and "output-oriented" perspectives, the latter focusing more closely on participation in governance and decision-making and the latter on the organization's effectiveness. Nowrot argues that the MSC and FSC differ in this respect, with the MSC taking a more top-down, technocratic approach, while the FSC relies more heavily on legitimacy derived from participation by a range of stakeholders. Nowrot argues that this poses a problem for the MSC, which it appears to have recognized-he notes the heavy investment by the organization to enhance its transparency and accessibility. Id. at 725 . See also Steven Bernstein \& Benjamin Cashore, Can Non-State Global Governance be 
adherence to (or at least acceptance of) structures and processes for governance and decision-making, the system would be too unstable: legitimacy is far too open-ended a concept and subject to radically different interpretations by the disparate group of actors that somehow must work together to make the system function. Similarly, science is dynamic, and scientists will disagree on answers to questions about whether a given resource is well managed or sustainably harvested or whether the risks associated with resource exploitation are acceptable. ${ }^{20}$ As in any society (or, in this case, societal fragment), the need for law becomes apparent: without it, the interactions of social systems networks, which the certification programs depend upon to be effective, would be significantly weaker and less stable. I will return to this point below.

The certification programs under discussion here are embedded in networks that facilitate the coupling of political-ethical goals (i.e. sustainable exploitation of resources and equitable exploitation and distribution of resources) and market signals (certification as a means of maintaining or increasing market share). ${ }^{21}$ The societal constitution permits an account of the Councils as political authorities and gives their certification programs (and the principles and standards on which they are based) formal legal validity. To date, the first of the two roles that Gunther Teubner attributes to the societal constitution has been accomplished: the Councils have constituted themselves and have given themselves the authority to promulgate rules. Through their interactions with civil society organizations, scientists, and industry actors, they have also constituted the network upon which the effectiveness of their certification programs relies. The second role-namely, the self-limitation of the social systems whose resources are drawn on-has not been fulfilled, though some tentative steps have been taken in this direction. ${ }^{22}$

Certification programs, possessing no legal or constitutional authority to impose norms or standards on industry actors, must instead rely on perceptions of their legitimacy and credibility. Certification organizations possess or command relatively few resources but must nevertheless be able to make credible threats and promises to industry regarding the impact that certification will have on their

Legitimate? An Analytical Framework, 1 REgUlation \& Governance 347 (2007); Cashore, supra note 18.

20. These are, of course, political questions, answers to which rely heavily on scientific expertise but which must ultimately be the object of political judgment.

21. For a discussion of the role of networks in creating interconnections among social systems, see Kjaer, supra note 8.

22. TEUBNER, supra note 9 , at 72-73. 
profitability. To do this, certification organizations must tap into the resources of a range of social systems and set in motion a series of translations from the medium of one system to another. The most important of these resources is the authority of natural and social sciences. This authority can be used to demonstrate that certification standards are grounded in solid expertise. It also demonstrates the authority of domestic and international law and policy; ethical or political objectives held by civil society organizations, opinion leaders, and citizens more generally; and the purchasing power of wholesalers, retailers, and consumers. Certification makes it possible for citizens to translate their ethical-political convictions, based on scientific information received directly or, more commonly, distilled by the media and opinion leaders, into purchasing decisions. Citizens can organize and bring pressure to bear on industry, but this pressure is often too diffuse to be effective. Citizens' ethical-political message is much more likely to be translated into the medium of money when they present themselves as consumers.

To create incentives for industry to certify their operations, opinion leaders and, ultimately, individual citizens must be convinced that it is worthwhile to opt for certified over noncertified products. This requires a perception that adherence to the requisite principles and standards makes a difference in the way in which resources are exploited. ${ }^{23}$ The standards on which certification is granted or withheld must be grounded in various forms of scientific and technical expertise. Civil society actors must also be convinced that the governance structures and decision-making processes of certification organizations are representative, inclusive, and accountable, such that they respect democratic principles, while at the same time being highly accessible to those possessing expertise. The Councils can bolster their legitimacy by constituting themselves and behaving as much like governments as possible and by compensating for their lack of governmental authority, notably by bolstering their democratic credentials. The governance structures and decision-making processes of the FSC and MSC were clearly constructed with these kinds of objectives in mind. A range of experts and stakeholders are represented within their governance

23. Cashore describes this as "pragmatic legitimacy." Cashore, supra note 18, at 518. This is to be distinguished from other types of legitimacy, namely moral and cognitive, on which the FSC and similar organizations rely. His framework for analyzing different types of legitimacy is drawn from Mark C. Suchman, Managing Legitimacy: Strategic and Institutional Approaches, 20 THE ACADEMY OF MANAGEMENT REV. 571 (1995).

These certification programs face significant challenges, and their effectiveness has been called into question. See Gulbrandsen, supra note 6, at $657 \mathrm{ff}$; Graeme Auld, Lars H. Gulbrandsen \& Constance L.McDermott, Certification Schemes and the Impacts on Forests and Forestry, 33 ANN. REV. OF ENVIRON. \& RESOURCES 187 (2008). 
structures, ${ }^{24}$ called on to comment on draft "legislation," 25 and given means to critique decisions on certification. ${ }^{26}$

The Councils' authority and the validity of their rules and standards are self-constituted. As Teubner argues with respect to international arbitration contracts, attention must be drawn away from the paradox of self-constitution in order for authority and validity to be well established. ${ }^{27} \mathrm{He}$ identifies three techniques to accomplish this: hierarchy, externalization, and the simple passage of time. ${ }^{28}$ Through their highly-formalized governance and decision-making structures, the FSC and MSC have clearly managed to establish a hierarchy among primary rules-the principles and standards to which organizations seeking or possessing certification are subject-and secondary rules that

24. The MSC's governance structure includes a Technical Advisory Board which advises the Board of Trustees, and which is consulted at various stages in the process of adopting standard. MSC Standard Setting Procedure 2.0. As for the FSC, a Working Group is established to develop standards and its members are selected on the basis of expert knowledge and representativeness. The Development and Approval of FSC Social and Environmental International Standards, FSC, FSC-PRO-01-001 (Version 2-0) (2006). The MSC's main governing body, the Board of Trustees, is advised by a Technical Advisory Board and a Stakeholder Council. The latter is comprised of a Commercial Chamber and a Public Interest Chamber. Structure, MARINE STEWARDSHIP CoUNCIL, http:/www.msc.org/about-us/governance/structure (last visited Oct. 1, 2013). Trustees are nominated by Board members and approved by consensus of the Board.

In the case of the FSC, the main governing body is the General Assembly, which is comprised of three Chambers: Social, Environmental and Economic. Each chamber is comprised of Southern and Northern subchambers. The Board of Directors is comprised of members who are elected from each chamber. Governance, FSC, https://ic.fsc.org/governance.14.htm (last visited Oct. 1, 2013).

25. Within the FSC, a Consultative Forum made up of potentially affected stakeholders is established when a new standards is proposed, and rounds of public consultations are held. Standard Setting, FSC, https://ic.fsc.org/standard-setting.212.htm (last visited Oct. 1, 2013).

Within the MSC, proposed standards are subject to public consultation and must be approved by the Technical Advisory Board (TAB), Steering Committee and Board of Trustees. MSC Standard Setting Procedure 2.0: The Review and Revision of Existing MSC International Standards and the Development of any New MSC International Standards, MARINE STEWARDSHIP COUNCIL, http://www.msc.org/documents/consultations (last visited Oct. 1, 2013). See also Gulbrandsen, supra note 6, at 33.

26. Both Councils have a complaints procedure that can be invoked by a wide range of actors. See FSC Procedure, Processing Formal Complaints in the FSC Certification Scheme, FSC, FSC-PRO-09-002 (V2-0) (2011), http:/www.fsc.org/proce dures.html (last visited Oct. 1, 2013); MSC Complaints Procedure (2011), MARINE STEWARDSHIP COUNCIL, http://www. msc.org/documents/consultations/MSC-Complaints-Procedure.pdf (last visited Oct. 1, 2013).

27. Gunther Teubner, 'Global Bukowina:' Legal Pluralism in the World Society, in Global LAW WITHOUT A STATE 3, 16 (1997); Lawson \& Cashore, supra note 16, at 13.

28. Teubner, supra note 27. 
govern the creation, ${ }^{29}$ modification, and application of those primary rules, including dispute resolution. ${ }^{30}$

Care is also taken to enhance the rigor of substantive and procedural rules through externalization. We see evidence of this in the process of accreditation itself, which is handled by third-party accreditors who are themselves certified by another independent organization, Accreditation Services International (ASI). ${ }^{31}$ In addition, the programs are measured against a series of external benchmarks and standards. ${ }^{32}$ Furthermore, both Councils belong to the ISEAL Alliance, an umbrella organization for certification programs. ISEAL has also

29. In the FSC, the crafting of international standards is highly structured and subject to widespread publicity and public comment. Primary responsibility for drafting a new standard lies with a Working Group, overseen by a Steering Committee which ensures compliance with applicable procedures. Final approval authority lies with the Board of Directors. See Standard Setting, supra note 25.

As for the development of regional and national standards, FSC International is involved in two main ways: first, it provides fairly detailed rules to regional and national organisations on the development of standards. FSC International Standard-Structure and Content of National Forest Stewardship Standards, FSC, FSC-STD-60-002 (V 1-0) (2009), http://www.fsc.org/national_ standards.html (last visited Oct. 1, 2013). It also provides fairly detailed guidance. FSC Guideline: FSC Forest Stewardship Standards: Structure, Content and Suggested Indicators, FSC, FSC-GUI-60-001 (V 1-0) (2010), http://www.fsc.org/194.html (last visited Oct. 1, 2013). Second, regional and national policies and standards are subject to approval by FSC International. Structure and Content of National Forest Stewardship Standards, supra.

The MSC's procedure for the development of principles and standards is less developed but nevertheless provides for extensive publicity and comment. Standard-Setting Procedure 2.0, supra note 25.

30. Within the FSC, provision is made for appeals from accreditation decisions and from decisions of the FSC itself. FSC Procedure-Processing Appeals, FSC, FSC-PRO-01005 (v 2-1) (2011), http://www.fsc.org/documents.html (last visited Oct. 1, 2013). There are also procedures for the submission to the FSC and ASI of informal complaints. FSC Procedures-Processing Complaints, FSC, FSC-PRO-01-008 (V 1-0) (2009), http://www.fsc.org/documents.html (last visited Oct. 1, 2013). Formal complaints also have designated procedures. FSC Procedure-Processing Formal Complaints in the FSC Certification Scheme, FSC, FSC-PRO-01-009 (V . 2-0) (2011), http://www.fsc.org/documents.html (last visited Oct. 1, 2013).

The MSC has a procedure for objecting to a decision on certification which is structured along the lines of judicial review. MSC Certification Requirements, v. 1.2, Jan. 10, 2012, Annex CD, at C139 ff., http://www.msc.org/documents/scheme-documents/mscstandards/MSC_environmental_standard_for_sustainable_fishing.pdf/ view (last visited Oct. 1, 2013).

31. Third Party Certification, Marine STEwaRDShIP CounCIL, http://www.msc.org/ about-us/standards/third-party-certification (last visited Sept. 14, 2013).

32. In the case of the MSC, these include criteria issued by the UN Food and Agricultural Organisation (FAO) intended to guide the certification process. Guidelines for the Ecolabelling of Fish and Fishery Products from Marine Capture Fisheries, Revision 1, UN FOOD AND AGRICULTURAL ORGANIZATION (2009), http://www.fao.org /docrep/012/i1119t/i1119t00.htm (last visited Oct. 1, 2013). 
issued guidelines on certification. ${ }^{33}$. ISEAL itself seeks to bolster its credibility by measuring its guidelines against those of other organizations, notably the International Standards Organisation (ISO) ${ }^{34}$ and those incorporated into the Agreement on Technical Barriers to Trade at Annex $3 .^{35}$ These appeals to external standards present practical advantages: the Councils, as well as ISEAL, are able to tap into the credibility and authority of well-respected nongovernmental and intergovernmental groups. In addition to constituting an interesting technique for deflecting attention away from the self-constituted nature of the Councils' authority, the codes of conduct promulgated by ISEAL, the FAO (Food and Agriculture Organization of the United Nations), and other organizations can be seen as an attempt to outline proto-constitutional principles for certification programs.

As for the third technique, reliance on the passage of time, these regimes are too new and their authorship of the certification standards still too much in evidence for certification to have taken on the kind of taken-for-granted quality possessed by many state-based (and some nonstate-based) rules. Still, the boundary between state-based and nonstate-based law in this area is being blurred in modest but potentially interesting ways. For example, a number of governmental authorities have sought and obtained accreditation from the MSC and FSC. ${ }^{36}$ In time, this interaction between state agencies and nonstate

33. Three sets of guidelines have been promulgated by ISEAL: the Code of Good Practice for Setting Social and Environmental Standards; the Code of Good Practice for Assessing the Impacts of Social and Environmental Standards; and the Code of Good Practice for Assuring Compliance with Social and Environmental Standards. Our Codes of Good Practice, ISEAL ALLIANCE, http:/www.isealalliance.org/our-work/definingcredibility/codes-of-good-practice (last visited Oct. 1, 2013). Work is currently underway on a set of Credibility Principles, which include clear objectives, transparency, openness to a range of stakeholders, measurable and objective criteria and impartial and independent verification of compliance with standards.

34. Comparison of Standard-Setting Code and WTO TBT, ISEAL ALLIANCE, R025, Version 3.0 (March 2010). The ISO standards to which comparison was drawn are the ISO/IEC Guide 59: Code of Good Practice for Standardisation (1994).

35. Comparison of Standard-Setting Code and WTO TBT, supra note 34; Centre for International Environmental Law and ISEAL Alliance, International Standards and Technical Barriers to Trade, R053-Legal Opinion Summary (July 2006).

36. As of December 2012, 22.6\% of certificates were issued for forests whose tenure was managed publicly. Global FSC Certificates: Type and Distribution, FSC, Jan. 2013, available at https://ic.fsc.org/download.facts-and-figures-january-2013.a-1622.pdf. Baden-Württemberg and Rhineland-Palatinate are seeking FSC certification for federal forests. FSC, ic.fsc.org (last visited Oct. 1, 2013). A number of governments have incorporated FSC standards into their legislation on forest conservation and management, for example by requiring FSC certification prior to permitting exploitation of forest products. Governmental Use of Voluntary Standards: Care Study 4, ISEAL ALLIANCE, Sept. 2008, available at http://www.isealalliance.org/sites/default/ files/R079_GUVS_Innovation_in_Sustainability_Governance_0.pdf. State-based agencies 
political authorities may come to obscure the latter's lack of a formal, state-based pedigree.

\section{From Legalization to Constitutionalism}

The central aim of certification programs is to influence the behavior of industry actors through economic incentives. The most apparent danger faced by such programs is the unlimited expansion of economic logic, such that it comes to drive the programs at the expense of the logics of other systems. ${ }^{37}$ This could mean, for example, that powerful industry actors, whose cooperation is deemed necessary to the success of the programs, could threaten to withdraw their cooperation if decisions do not go their way. It could also mean that the medium of money comes to be the only one that counts within the program, that all decisions are made with an eye to efficiency, and that other considerations are subordinated to this one-or worse, that other considerations cannot readily be spoken about because the language necessary to express them is not available within the structure of the program.

The certification programs put in place by the Councils seek to address these dangers by placing other logics front and center in decision-making processes. In other words, the certification programs do not represent an attempt by the economic system to impose limits on itself; the constitutional subject is the transnational, nongovernmental regime, and not the social system or subsystem. ${ }^{38}$ The Councils have set in motion this complex interaction among social systems, but they do not control it. On the contrary, the success of certification appears to depend on perceptions that the deployment of political-ethical convictions, scientific knowledge, and legal validity are not controlled by the Councils, but rather that those organizations are highly responsive to inputs from these systems.

The difficulty, made clear by the concept of the societal constitution, is that structural coupling between these various systems is highly imperfect and that the Councils are at risk of simply being buffeted about by confrontations among social systems that do not have

that have received MSC certification include the South Wales Sea Fisheries Committee, the Metlakatla Indian Community in Alaska, the Parties to the Nauru Agreement (Federated States of Micronesia, Kiribati, Marshall Islands, Nauru, Palau, Papua New Guinea, Solomon Islands and Tuvalu), and the Government of South Georgia and the South Sandwich Islands. MARINE STEWARDSHIP COUNCIL, www.msc.org (last visited Oct. 1, 2013). See Meidinger, supra note 7 , at 59 ff. for a discussion of governmental involvement in the FSC and other nonstate forest certification processes.

37. TEUBNER, supra note 9 , at 89.

38. Id. at $94 \mathrm{ff}$. 
reasonably effective means of communicating with one another. An excellent example of these confrontations among systems is provided by the poorly defined role of law within the networks constituted by the Councils' certification programs.

\section{A. Autonomy of the Law}

In order for law-or any social system-to carry out the roles and functions that are generally expected of it, it must maintain its autonomy from the other social systems with which it interacts. In fields such as the environment and human rights, this can be a difficult challenge because these bodies of law tend to depend heavily on other social systems-notably politics, ethics, and, in the case of the environment in particular, science. Translating the political objectives of environmental protection and the promotion of human rights into rules of law is a difficult task, and efforts in this direction often lead to the creation of mostly hortatory legal rules, simply because the articulation of legal rights or obligations and of standards by which to measure compliance is difficult to accomplish. Because law can accomplish things that other social systems cannot, the articulation of legal rules that do not depend heavily on operations within other social systems is essential. For example, it may make sense from a political, moral, or strategic point of view for a state to intervene in a civil war taking place in a neighboring state in support of a rebel group, but because there is no realistic way to make a generalizable category distinction between just and unjust rebellions, there is a legal rule against such intervention. ${ }^{39}$ In assigning responsibility to a firm for contributing to environmental harm, a court does not need to wait for a scientific report establishing the precise proportion of the firm's contribution to the harm; it can turn to a rule crafted by judges or legislators that apportions liability in a manner that is both politically and legally defensible even if "unscientific." 40 Nor are judicial conclusions subject to continual revision and updating as new knowledge or understanding emerges. Legal conclusions, unlike ethical judgments, do not address the goodness of people or the rightness of

39. Declaration on Principles of International Law concerning Friendly Relations and Cooperation among States in accordance with the Charter of the United Nations, A/RES/25/2625 (Oct. 24, 1970).

40. Restatement of the Law (3d): Torts, AMERICAN LAW INSTITUTE, §8-Factors for Assigning Shares of Responsibility; $\S A 18$-Liability of Multiple Tortfeasors for Indivisible Harm. The Québec Civil Code apportions liability among multiple defendants not according to their respective contributions to the injury, but "in proportion to the seriousness of the fault of each." Civil Code of Québec, art. 1478. 
action and, thus, can possess validity across different communities organized around faith or a particular set of values.

The kind of arbitrariness that exists in law, environmental law in particular, would not likely be acceptable in other spheres such as politics or science. Importantly, this is not due to any failings or weaknesses of law as it cannot be otherwise if law is to maintain its distinctiveness as law, and not collapse into politics or science. However, if law is to be used to pursue objectives such as sustainability or equity, this distinctiveness must be explicitly protected. A difficulty currently faced by the FSC and MSC, which will only grow more acute as the power and influence of these organizations grow, is that the boundary between law and other social systems is, despite the high degree of formality of the organizations' governance structures, highly porous.

An analysis of the structure of the Councils' rules suggests the presence of a good deal of uncertainty regarding how scientific and technical expertise can influence both political decisions concerning the setting of standards and criteria and legal decisions concerning the application of these standards. Both Councils have developed several layers of rules, ranging from broad principles that more closely resemble political objectives to highly detailed and specific criteria, indicators, and scoring guidelines that, superficially at least, are structured as procedural rather than substantive rules. ${ }^{41}$ Even then, these guidelines are very often applied substantively through the performance of scientific operations.42 For example, both Councils have developed criteria that environmental assessment and management plans for resource extraction must meet. ${ }^{43}$ The procedural form of these criteria suggests that legal operations could be performed on them, but if interpretation and application of the criteria were left to the operations of the legal system, questions as to whether a resource is well managed or sustainably exploited could not be answered in any other than a

41. The FSC has articulated 10 principles, accompanied by broad criteria. Further standards are developed at a regional and national level; the development of these standards is subject to guidelines articulated by FSC International, which must also approve the standards.

The MSC has developed 3 principles and broad criteria, as well as a highly detailed set of indicators and scoring guidelines; in addition, accreditors develop a further, more carefully tailored, set of indicators for each certification process.

42. The assessment reports are prepared by teams with strong scientific knowledge and often some policy and economic expertise; their methodology, structure, and substance is drawn largely from the sciences. See, e.g., Food Certification International Ltd., MSC Sustainable Fisheries Certification, AGARBA Spain Barents Sea Cod Fishery: Public Comment Draft Report, July 2013.

43. FSC Principles and Criteria for Forest Stewardship, FSC, FSC/STD/01/001 (V05-0), Principle 7: Management Planning; MSC Fishery Standard: Principles and Criteria for Sustainable Fishing, Marine STEWARDshIP CouncIL, Principle 3 (May 1, 2010). 
purely formal-and highly unsatisfactory-manner. In short, subjecting these criteria to legal expertise would miss the point. The potential danger posed by the structure of the Councils' rules is that the legal form is taken up in a superficial way in an attempt to lend the stability and predictability associated with legal rules and regimes to the scientific and social-scientific endeavour of developing resource management plans.

An interesting illustration of this phenomenon is the manner in which the requirement that certified bodies respect applicable domestic and international law is evaluated. This is the type of issue on which legal operations could be carried out, but the approach of both organizations is to identify a series of proxies that permit accreditors to verify compliance with domestic laws, including the level of familiarity of the certified body's staff 'members with applicable laws, the possession by the certified body of up-to-date copies of relevant statutes and regulations, and the satisfaction of legal requirements such as registration with national authorities and payment of license fees. ${ }^{44}$ These and the other "verifiers" may be reasonably good ways of measuring compliance, but they fall well short of calling for the interpretation and application of domestic and international rules by accreditors. This is likely due to reluctance to appear to be treading on the jurisdiction of national and regional authorities, but it provides an excellent illustration of the distance that is placed between what is being measured and what the measurement stands for. The use of proxies and indicators is unavoidable-accreditation bodies cannot provide direct answers to questions such as, "is this resource exploited sustainably?" Instead, they must answer the question indirectly by performing operations that permit resource exploitation to be placed in either the "certifiable" or the "uncertifiable" category. The issue here is that the proxies being used-apparently for the purpose of making the process of measurement repeatable, verifiable, and transparent-may in fact make it difficult for any of the social systems to make the kinds of contributions that are expected of them.

In practice, the standards tend to be viewed as substantive, not procedural. That is, accreditation bodies do not take a purely formal approach to evaluating the quality of a management plan; they instead carry out scientific operations, at least to a limited extent, to determine whether various standards and criteria are satisfied. ${ }^{45}$ This makes a good deal of sense, given the types of questions that must be answered

44. See, e.g., FSC Guideline: FSC Forest Stewardship Standards, supra note 29.

45. Lawson and Cashore argue that the standards applied by certifiers must operate as legal standards, but that the certification decisions must be scientifically based. Lawson \& Cashore, supra note 16, at 20 
in order for a determination on certification to be made. While one can imagine various ways in which the legal system could or should be implicated in the making of these decisions, it makes little sense to attempt to transform a decision-making procedure that requires inputs from a wide range of expert and lay bodies of knowledge into a series of legal operations. The structure of the Councils' rules suggests a good deal of uncertainty as to how to classify the operation (science, policy, law?) and as to how to structure the relationships among these and other social systems.

Another example of the tensions and overlap among social systems is provided by the process put in place by the MSC for objections to certification decisions. ${ }^{46}$ This procedure very closely resembles judicial review. Its stated objective is not "to review the subject fishery against the MSC Principles and Criteria for Sustainable Fisheries, but to determine whether the certification body made an error that materially affected the outcome of its Determination." 47 The procedure is fairly formal, ultimately involving a hearing before an adjudicator, following which a decision can be taken to remand the certification decision to the certification body. ${ }^{48}$ At present, the adjudicators are all lawyers. ${ }^{49} \mathrm{On}$ one level, this makes perfect sense, as the object of the resolution of disputes regarding certification decisions cannot be to resolve political or scientific controversy, but rather to determine whether the rules and procedures were respected. However, given the heavy dependence of accreditation reports on scientific expertise, concerns are raised that the adjudicators would have to possess expertise in fisheries biology, fisheries management, and/or marine ecology, ${ }^{50}$ or they would need to rely heavily on their technical advisors. ${ }^{51}$ The question is whether-given the nature of MSC principles, standards, criteria, and indicators-judicial review of certification decisions can serve the kinds

46. MSC Certification Requirements, supra note 30 (Objections Procedure, Annex CD).

47. Id. at para. CD 2.1.1.1.

48. Id. at para. CD 2.7.2. The critoria include serious errors that made a material difference to the outcome; unjustifiable scores resulting from a mistake, failure to consider relevant information, or arbitrary and unreasonable exercise of discretion.

49. Independent Adjudicators-Biographies, MARINE STEWARDSHIP COUNCIL, www.msc.org (last visited Oct. 1, 2013).

50. Jennifer Jacquet \& Daniel Pauly, Seafood Stewardship in Crisis, 467 NATURE 28, 28 (2010). Jacquet and Pauly bemoan the lack of fisheries expertise and the "bureaucratic" rather than "biological" nature of the objections procedure. The process of judicial review is not (or at least should not be) bureaucratic, and it is possible that the authors are making a category mistake. Nevertheless, given the nature of the standards whose applications the adjudicators are to evaluate, serious questions may be raised about the relevance of legal expertise to the process.

51. Adjudicators may call on "technical advisors." MSC Certification Requirements, supra note 46 , at s. 4.7 . 
of purposes that it is meant to serve in other areas of administrative law-namely, to maintain certain standards of procedural fairness and to prevent abuse of authority by administrative decisionmakers.

In order to understand what roles law could play and what contributions it could make to the Councils' certification programs, we must have some perspective on the proprium, or the form, of law.

\section{B. The Form of Law}

Autopoietic theory itself avoids providing a definition of law, either from the inside (i.e. a definition that would make sense to jurists and others who work within the legal system by participating in its operations) or from the outside (i.e. a definition that would make sense to those who interact with the legal system by concluding contracts, suing or being sued, or seeking to bring their behavior in conformity with legal rules) beyond the identification of the binary code (legal/illegal; law/not law), ${ }^{52}$ which the legal system uses to communicate with its environment. This is because the contents of the legal system-its program-are contingent, resulting from the manner in which law receives, interprets, and performs operations on inputs and responds to irritations. ${ }^{53}$ Over time, certain self-understandings about law's roles and functions, along with descriptions of the legal system generated within other legal systems and understandings of the

52. This distinction is often misconstrued as proceeding from a functional definition of law as command and thus as reducing all of law to the kinds of commands and prohibitions typical of substantive rules of criminal law. Michael King and Chris Thornhill argue, however, that this has much to do with the fact that Recht/Unrecht cannot be translated directly into English as a single pair of concepts. They note that the application of the binary distinction will vary depending on the type of issue to which the legal code is being applied. For example, in private law, the application of the distinction lawful/unlawful will be treated as focusing attention on the "lawful" side of the code: being right in law. In criminal law, the "lawful" side will be treated as the residual category. At other times, the two sides of the code will represent, respectively, communications that the law recognizes are relevant to the legal system (the contract was not notarized) and those that it does not (the defendant wore a red tie). King and Thornhill state: "The subtlety and complexity of the relationship between Recht and Unrecht and the flexibility with which it may be adapted by the legal system's programmes to suit the particular situation are unfortunately and inevitably lost in translation, owing to the need to change the English words according to the context in which they are used." MICHAEL KING \& CHRIS THORNHILL, NIKLAS LUHMANN'S THEORY OF POLITICS AND LAW 56-7 (2006). For a discussion of the operation of the binary code in nonstate law, see Gunther Teubner, The Two Faces of Janus: Rethinking Legal Pluralism, 13 CARDozo L. REV. 1443, 1451 (1991-1992).

53. Gunther Teubner, LAW AS AN AUTOPOIETIC SYSTEM 79 (1993). 
legal system held by members of society, will develop. Such understandings are encapsulated in the concept of the rule of law.

Classic formulations of the rule of law emphasize "[g]overnmental action . . . based on clearly formulated, publicly declared rules" as opposed to rule by decree or prerogative. ${ }^{54}$ Generality was also considered crucial to the rule of law as ensuring the depersonalized, impartial exercise of political authority ${ }^{55}$ According to other criteria associated with the rule of law, legal rules must be clear, knowable by the public, prospective, and stable. ${ }^{56}$ With the advent of the welfare state, a challenge to the rule of law other than that of tyranny emerged, described by Roberto Unger as a contemporary tendency toward "deformalized 'materialized' regulatory law." 57 One manifestation of this phenomenon is the promulgation of vague, general standards such as compatibility with the public interest, the best interests of the child, or, in the case of environmental law, concepts like ecosystem integrity or sustainable use. ${ }^{58}$ William Scheuerman aptly describes the potential dangers of this tendency:

Can this subordination [of the administration to law] amount to very much when an administrator is told simply to decide what the public interest amounts to or when a judge is asked to determine what is unconscionable about a contract? Might not the rule of law be more honestly described as a "rule of indeterminate resolutions," and does not the distinction between legal and illegal administrative action risk becoming unclear? There can be no broad agreement about what "good morals," "good faith," or "unconscionable" action means in complex, morally heterogeneous societies. 59

Another consequence is the specification of increasingly dense networks of norms and standards to which recipients of various forms of state assistance and other subjects of social justice law are expected to

54. William E. Scheuerman, Between the Norm and the Exception: The FRANKFURT SCHOOL AND THE RULE OF LAW 69 (1994).

55. Id. at 69-70.

56. William E. Scheuerman, Frankfurt School Perspectives on Globalization, DEMOCRACY, AND THE LAW 30 (2008).

57. ROBERTo Unger, LAW IN MODERn SOCIETY 193 ff. (1976). See also SCHEUERMAN, supra note 56 , at 94 .

58. SCHEUERMAN, supra note 56, at 94-95.

59. Id. at 94 . 
conform. Both manifestations of materialized law are heavily "dependent ... on implementation of each program by a continuous administration (instead of controls through occasional legal pronouncements, as in formalized legal programs)."60 In the field of social welfare law, the realm of freedom and autonomy of its beneficiaries is reduced. ${ }^{61}$

The law of social justice has much in common with environmental law; 62 both are concerned not simply with creating the conditions for the realization of certain ends that are defined elsewhere, but also with the bringing about of certain states of affairs. Both are characterized by materializing tendencies: they move from vague, general pronouncements to highly detailed, technical criteria and indicators. Arguably, the detailed standards are drafted in response to concerns about the slipperiness of grand principles such as "develop sustainably" or "respect biological diversity," whereas the grand principles are present to give some necessary guidance to those charged with interpreting and applying the detailed criteria. The problem is that the criteria and indicators of the type that appear in the legal texts promulgated by the Councils contain little on which the legal system can gain purchase. Either their interpretation and application depends on the input of scientific and technical expertise and requires more than just legal expertise for their interpretation and application, or they have been transformed into proxies for good scientific research and sound resource management that may be too far removed from the actual enterprises of scientific and resource management to be meaningful.

In order to better understand the respective roles of law and other social systems-notably politics and science-in the application of the Councils' rules, let us consider what decision-making might look like if law played no significant role. If law's contribution were absent, the Councils would depend exclusively on feedback from political, scientific, and economic systems. Whenever a controversy arises, the Councils need to manage it as quickly and as thoroughly as possible, since defection of disillusioned or disaffected actors could easily be fatal to the network. Thus, when a group feels that it was not adequately represented or consulted when a decision is taken or when there is a

60. Rudolph Wiethölter, Materialization and Proceduralization in Modern Law, in Dilemmas of LaW IN THE Welfare STATE 226 (Gunther Teubner ed., 1988).

61. JÜRGEN HABERMAS, BETWEEN FACTS AND NORMS: CONTRIBUTIONS TO A DisCOURSE THEORY OF LAW AND DEMOCRACY 416 (1998). From the point of view of the legal system, the result is to "overstrain" the system. Niklas Luhmann, The Self-Reproduction of Law and its Limits, in DILEMMAS OF LAW IN THE WELFARE STATE, supra note 60, at 111, 124.

62. It is probably not appropriate to regard environmental law as separate from social justice law; the latter is, rather, a subcategory of the former. 
scientific controversy regarding the soundness of a standard or a certification report, the legitimacy and authority of the Councils are called into question. If serious doubt is cast on a decision or action by the Councils, their ability to proffer credible economic threats and promises to industry actors is weakened. This leaves the Councils extremely vulnerable to such controversies, which are inevitable and ongoing. The Councils, any more than state governments, cannot wait for scientific controversy to be settled or for perfect consensus to emerge among stakeholders. Councils depend on a high degree of confidence on the part of network members in the structures and processes put in place to reach reasonable conclusions on scientific and political issues, such that those members will maintain their participation in the network even when decisions do not go their way. This cannot be accomplished on the strength of political legitimacy and scientific authority alone. The Councils require political authority, which confers the capacity to enact valid law.

\section{Some Thoughts on the Restructuring of Environmental Law}

The difficulties of creating policy objectives and legal rules in the environmental field, where dependence on scientific expertise developed in complex and uncertain conditions is heavy, are immense. As Karl-Heinz Ladeur notes, environmental law is conditioned by the "necessity of decision-making under conditions of uncertainty." 63 In the recent past, the concept of causation could be relied on to build bridges between law, science, policy, and other fields: causation was never, Ladeur emphasizes, a scientific concept that permitted simple descriptions of phenomena in the natural world but rather a construction with normative implications. ${ }^{64}$ Nevertheless, it did permit reasonably smooth communications among social systems, as causation could serve as a kind of boundary object that, although conceived of differently in each social system, permitted relatively stable interactions among them. ${ }^{65}$ Ladeur notes, however, that the sciences are slowly moving away from causal models toward new paradigms that seek to better model the complexity of the natural world and that are much less likely to produce stable, reproducible observations. ${ }^{66}$

Ladeur argues that, since causation is a social construction, a new, more appropriate heuristic can be created that can permit interaction

63. KH LADEUR, DAS UMWELTRECHT DER WISSENSGesellschaFT: VON DER GEFAHRENABWEHR ZUM RISIKOMANAGEMENT 11 (1995) (translation by author).

64. Id. at 15 .

65. Id. at 83 .

66. Id. at $84-85$. 
among social systems. As science seeks to come to terms with complexity and uncertainty, law must become more dynamic and flexible, more open to progressive development. ${ }^{67}$ Ladeur proposes risk as the concept around which decision-making procedures must be organized. ${ }^{68}$ Because research into the existence of risk could be never ending, "stop rules" must be crafted that make it possible to stop asking questions and make a decision but that also attract a certain level of trust. These rules, like the stop rules that allowed causal models to function, cannot be constructed on the basis of scientific or technical inputs alone, since they must attract the confidence not just of the scientific community but also of the range of other social systems that are implicated in their interpretation and application. ${ }^{69}$ These stop rules are procedural in nature, guiding and shaping methods of risk assessment and analysis. ${ }^{70}$ This has many implications for the shape of legal rules and institutions. Ladeur argues that rules must be structured to maximize the capacity for learning, ${ }^{71}$ for example through the emergence of hybrid institutions that straddle but, importantly, do not seek to overcome boundaries among social systems. ${ }^{72}$

Two questions arise: first, whether the Councils foster or create room for developments along the lines sketched above; second, whether these developments are compatible with our current conceptions of the nature and role of law. If the answer to the second question is no, then autopoietic theory might predict a gradual reorientation of the legal system in which its code may remain the same but its self-definition might take on a different shape.

It might be possible to rethink the interactions among science, policy, and law in the context of the Councils' principles and standards so as to avoid the dangers of deformalization and materialization. We are in the realm of so-called post-normal science, that is, issue-areas characterized by uncertainty, complexity, and salience. Political and economic stakes are high, but scientists are not in a position to provide clear answers to questions about the nature and significance of risks. ${ }^{73}$ As Ladeur argues, the crafting of resources management and exploitation policies must proceed on an essentially experimental

67. Id. at 11.

68. Id. at $78 ; 84-89$.

69. Id. at 87 .

70. Id. at 151 .

71. Id. at 155 .

72. Id. at 149 .

73. SO FunTOWICZ \& JR RAVETZ, Uncertainty, Complexity and Post-normal Science, 13 ENVIRON. TOXICOLOGY \& CHEMISTRY 1881, 1882 (1994). 
basis, ${ }^{74}$ including multiple opportunities for assessment and reassessment and adjustment of rules and practices as necessary. Furthermore, because of the difficulty of communications between social systems, regimes must be designed to keep these systems in constant contact with one another, providing many opportunities for mutual irritation. ${ }^{75}$ Autopoietic theory would describe this process in terms of the disappointed expectations of, for example, scientists on the one hand and political authorities on the other, leading to irritations to each system that may result in revisions to the programs in which these actors participate. In particular, the model that the political system constructs for the nature and production of scientific knowledge could come to be more sophisticated, though of course this sophistication can never reach the point at which scientific meaning can be received directly and immediately by the political system.

The Councils have taken many important steps in these directions. Their structures and processes are designed to keep scientists in constant contact with industry and civil society actors. The provisional nature of certification, subject in both regimes to regular assessment and reconsideration, ought to make it more difficult for actors to acquire de facto rights to certification and make it necessary for them to continue to renew their efforts to meet the broad objectives articulated by the Councils. It is not enough for them to simply proceed with the implementation of a management plan that has received a stamp of approval. The standards themselves are subject to regular reevaluation. But a larger question emerges-namely, whether the flexibility and dynamism that these regimes work hard to maintain, and that

74. LADEUR, supra note 63, at 94. See also BRUNo LATOUR, POLITIQUeS DE LA NATURE: COMMENT FAIRE ENTRER LES SCIENCES EN DÉMOCRATIE $231 \mathrm{ff}$. (2004); KERRY H. Whiteside, Precautionary Theory: Science, Uncertainty, and Political Authority, in Precautionary Politics: Principle and Practice in Confronting Environmental RISK 109-11 (2006).

75. The concept of the "boundary organization" has received a good deal of attention in this respect: these organisations experiment with different ways of bringing together different kinds of knowledge and expertise, with a view to solving or at least addressing particular problems. One of the more famous examples is the Intergovernmental Panel on Climate Change, created by the United Nations Environment Program and the World Meteorological Organisation 'provide the world with a clear scientific view on the current state of knowledge in climate change and its potential environmental and socio-economic impacts:' http:/www.ipcc.ch /organization/organization.shtml\#.UBa812HbCYQ. See C. MHILE, Hybrid Management: Boundary Organizations, Science Policy, and Environmental Governance in the Climate Regime, 26 SCIENCE, TECHNOLOGY \& HUMAN VALUES 478 (2001); CLARK A MHLER, Challenges in the Application of Science to Global Affairs: Contingency, Trust, and Moral Order, in CHANGING THE ATMOSPHERE: EXPERT KNOWLEDGE AND ENVIRONMENTAL GOVERNANCE, 478 (Clark A. Miller \& Paul N. Edwards eds., 2001). See also Karl-Heinz Ladeur's discussion of "hybrid institutions" in LADEUR, supra note 63, at 149. 
post-normal science demands, are compatible with the form of law. The answer, I believe, is a qualified yes. In important respects, the considerations that are central to the rule of law, and more specifically the concerns that have emerged regarding materialized law, converge with the challenges of decision-making under conditions of uncertainty. Whether one favors certainty and predictability or flexibility and dynamism, the inappropriateness of detailed legislation that accompanies actors and the things they produce along a carefully constructed path from cradle to grave becomes apparent, though for different reasons. On the other hand, the dynamism and flexibility called for by Ladeur and others may seem difficult to reconcile with the stability and predictability that we have come to associate with law. A closer look at the kinds of criteria generally associated with the rule of law, however, indicates that keeping actors' obligations constantly in motion as understandings evolve could be managed in a manner compatible with rule of law objectives such as clarity, knowability, and the prospective nature of legal rules. To return to the example of the management plan, while it is true that actors seeking to obtain or retain certification do not know precisely what kinds of practices and measures they will need to engage in to maintain certification, they do know that they will have to maintain programs of research and assessment and to foster links with a range of different communities-local and epistemic. Their obligations can be seen as stable, if one ceases to consider the substantive obligations as the main focus of attention, as these ought to be a moving target if the regime is to function as it should.

One function of law that cannot readily be accomplished by the Councils or within their networks as currently constituted is apportionment of liability. Given that certification, the Councils' standards, and the management plans developed by industry actors possess an experimental quality, attention must turn at some point to the processes that ought to be set in motion when these experiments go terribly wrong. The threat of withdrawal of certification is unlikely to provide an adequate incentive in the face of significant financial gains from resource exploitation and the likelihood that industry actors can point to uncertainty and scientific controversy if their management plans turn out to be inadequate. A much stronger incentive to carry out rigorous and extensive assessments and to make necessary allowances for potential shortcomings in management plans would be provided by the threat of liability. ${ }^{76}$ This would require the establishment of much stronger connections between Council law and state-based law.

76. Gunther Teubner, The Invisible Cupola: From Causal to Collective Attribution in Ecological Liability, in ENVIRONMENTAL LAW AND ECOLOGICAL RESPONSIBILITY: THE 


\section{CONCLUSION}

As the Councils and their certification programs are currently configured, law appears to be conceived of mainly as a conduit among the various systems implicated in the networks. The rules structure the contribution of politics to the network by defining the roles of various groups of stakeholders and creating fora and channels for participation and feedback. However, the rules are far from having a life of their own. At present, the emphasis is on legitimacy and credibility rather than validity, and serious questions remain regarding the extent to which the rule of law is respected. Indeed, the nature of environmental decisionmaking renders necessary an extensive reflection about the role that law can usefully play.

In the networks constituted by the FSC and MSC, the process of constitutionalism has proceeded far enough to make available the resources of politics, economics, and science to the certification networks, but not far enough to establish boundaries among those systems. Within the network, law risks being swamped by these other systems. ${ }^{77}$ Further, the potential contributions that law could make, as an autonomous social system and not merely as a system of conduits connecting other systems to the network, are not readily apparent.

The Councils' certification programs are interesting and important experiments in environmental governance, not only because they rely on state-based authority only incidentally, but also because of the manner in which rulemaking and decision-making is constituted. No clear division of labor among the social systems and bodies of expertise brought together within the Council's network can be hoped, or even wished, for, but in time each of these social systems may come to develop more sophisticated models of the others. Just as biology is seeking to develop more sophisticated methodologies that are better suited to account for the complexity of ecosystems, law could, for example, develop more sophisticated operations for scientific inputs. This will be necessary in order for law (and politics) to be in a position to address scientific uncertainty, coding it not as ignorance or absence of proof of risk, but rather as provisional or partial knowledge.

At the same time, the constitution of these networks must enable them to look outward at cognate regimes and bodies of law. The

CONCEPT AND PRaCtice of ECOLOGICAL SELF-ORGanization, 17 (Gunther Teubner, et al. eds., 1994).

77. Similarly, as Jean-Christophe Graz notes, the autonomy of politics is endangered by the process of convergence, or structural coupling, that these networks bring about. International Standards and the Service Economy, in KARL POLANY, GLOBALISATION AND THE POTENTIAL OF LAW IN TRANSNATIONAL MARKETS, supra note 14, at 209, 218. 
incorporation by reference of domestic and international resource exploitation law, and, in the case of the FSC, labor, human rights, and other bodies of social justice law, has to date resulted in only superficial connections among these bodies of law. As the Councils gain influence and their certification programs come to have a wider impact, conflicts between Council law and other sets of normative expectations will increase in frequency and intensity. 
